\title{
The Appointment of a Proxy "At Any Time" in \\ Terms of Section 58 of the Companies Act 71 \\ of 2008: Richard Du Plessis Barry v Clearwater \\ Estates NPC [2017] ZASCA 11
}

V Madlela*

\section{P.E.R}

Pioneer in peer-reviewed, open access online law publications

Author

Vela Madlela

Affiliation

University of South Africa

Email madlev@unisa.ac.za

Date of submission

6 February 2018

Date Revised

6 February 2018

Date Accepted

16 November 2018

Date published

7 January 2019

Editor Dr G Viljoen

How to cite this article

Madlela $\mathrm{V}$ "The Appointment of a Proxy 'At Any Time' in Terms of Section 58 of the Companies Act 71 of 2008: Richard Du Plessis Barry $v$ Clearwater Estates NPC [2017] ZASCA 11" PER / PELJ 2019(22) - DOI

http://dx.doi.org/10.17159/17273781/2019/v22i0a4401

Copyright

DOI

http://dx.doi.org/10.17159/1727-

3781/2019/v22i0a4401

\begin{abstract}
Section 58(1) of the Companies Act 71 of 2008 gives a shareholder the right to appoint a proxy "at any time" for the purpose of participating in, speaking and voting on behalf of that shareholder at a shareholders' meeting, or providing or withholding written consent on behalf of the shareholder in terms of section 60. One important issue that arises in regard to the appointment of a proxy relates to the proper interpretation of section 58(1) of the Companies Act 71 of 2008, namely whether this section, as read with section $58(3)(c)$, constitutes an unalterable provision giving a shareholder an unlimited right to appoint a proxy "at any time" before the proxy exercises the shareholder's rights at the shareholders meeting, or whether the time period within which the instrument of a proxy's appointment must be delivered to the company may be restricted by the MOI. This issue was considered by the SCA in the Richard Du Plessis Barry case in view of the appellant's contention that the provisions of the $\mathrm{MOI}$ that limited the time period within which the instrument appointing a proxy must be delivered to the company, or other person on behalf of the company, were valid. In this note, I examine the Richard Du Plessis Barry case with a focus on the proper interpretation of the right of a shareholder to appoint a proxy "at any time" as conferred by section 58(1) of the Companies Act 71 of 2008. provide some critical comments on the main issues that this judgement raises, including the interpretation of section 58(1) in the context of "alterable" and "unalterable" provisions of the Companies Act 71 of 2008, a purposive interpretation of section 58(1), the interaction between section 58(1) and section 58(3)(c), the significance of the difference in the wording of section 58(1) of the Companies Act 71 of 2008 and section 189 of the previous Companies Act 61 of 1973, as well as the practical implications of the court's decision in this matter. This is followed by a brief comparative analysis with selected international jurisdictions and some concluding remarks.
\end{abstract}

\section{Keywords}

Proxy; representation by proxy; appointment of proxy; proxy giver; proxy receiver; proxyholder; shareholders' meetings; alterable provision; unalterable provision; section 58 of the Companies Act 71 of 2008; the Richard Du Plessis Barry case. 


\section{Introduction}

In Richard Du Plessis Barry v Clearwater Estates NPC [2017] ZASCA 11 (hereafter the Richard Du Plessis Barry case) ${ }^{1}$ the Supreme Court of Appeal (hereafter the SCA or the court) dealt with the proper interpretation of section 58(1) and 58(3)(c) of the Companies Act 71 of 2008 regarding the appointment of a proxy. Notably, the term "proxy" has frequently been used indiscriminately to refer to both the person who is appointed by a shareholder to represent that shareholder at a shareholders' meeting and the instrument or document by which a shareholder appoints such person. ${ }^{2}$ Although the Companies Act 71 of 2008 does not specifically define the term "proxy", 3 it is quite clear from the provisions of section 58(1) of the Companies Act 71 of 2008 that the term is used to describe an individual, including an individual who is not a shareholder of the particular company, who has been appointed by a shareholder to represent that shareholder at a particular shareholders' meeting. ${ }^{4}$

Section 58(1) of the Companies Act 71 of 2008, which has been described as an "enabling provision" 5 in this context, gives a shareholder the right to appoint a proxy "at any time" for the purpose of participating in, speaking and voting at a shareholders' meeting on behalf of that shareholder, or providing or withholding written consent on behalf of the shareholder in terms of section 60 . The notice of meeting must contain this right to appoint a proxy. ${ }^{6}$ To be valid, a proxy appointment must be in writing, dated, and signed by the shareholder. ${ }^{7}$ The proxy appointment is valid for one year or for a specific period as set out in the appointment unless it is revoked or

Vela Madlela. LLB, LLM (University of the Witwatersrand). Senior Lecturer, Department of Mercantile Law, University of South Africa. Email:madlev@unisa.ac.za.

$1 \quad$ Richard Du Plessis Barry v Clearwater Estates NPC [2017] ZASCA 11 (16 March 2017) (hereafter the Richard Du Plessis Barry case).

$2 \quad$ Nuwe Suid-Afrikaans Prinsipale Beleggings (Edms) Bpk v Saambou Holdings Ltd 19924 SA 387 (W) 390; Cassim et al Contemporary Company Law 365; and Davies et al Companies and Other Business Structures 98.

$3 \quad$ The meaning of the term "proxy" may vary from one jurisdiction or context to another. See, for example, s 147 of the Canada Business Corporations Act, 1985 which defines "proxy" to mean "a completed and executed or ... signed form of proxy by means of which a shareholder appoints a proxyholder to attend and act on the shareholder's behalf at a meeting of shareholders". Also see Cassim et al Contemporary Company Law 365.

$4 \quad$ This meaning assigned to the term "proxy" is different from the definition of a "proxy" in terms of $s 147$ of the Canada Business Corporations Act, 1985. It is also different from the meaning that is frequently assigned to a "proxy" as an instrument through which a person is appointed to represent a shareholder at a meeting. See Cassim et al Contemporary Company Law 365.

$5 \quad$ Stein and Everingham New Companies Act Unlocked 205.

Section 62(3)(e) of the Companies Act 71 of 2008.

Section 58(2) (a) of the Companies Act 71 of 2008. 
expires earlier. ${ }^{8}$ Section 58(3) of the Companies Act 71 of 2008 provides for a degree of "flexibility" in the appointment of proxies. ${ }^{9}$ In terms of this provision, "except to the extent that the Memorandum of Incorporation provides otherwise", a shareholder may appoint more than one proxy, ${ }^{10} \mathrm{a}$ proxy may delegate his or her authority to act on behalf of a shareholder to another person ${ }^{11}$ and, more importantly for the purposes of this note, a proxy appointment must be delivered to the company or other person on behalf of the company "before the proxy exercises any rights of the shareholder at a shareholders' meeting". ${ }^{2}$ The rationale for allowing representation by proxy is to promote the exercise of shareholders' governance rights in companies, given the highly globalised nature of the corporate world, cross-border investing, shareholder dispersion and poor shareholder attendance at general meetings. Representation by proxy would also allow a shareholder who may generally lack capacity and expertise to evaluate certain corporate matters or complex transactions to appoint a person with the necessary capacity and expertise to engage company boards and to make decisions concerning such matters or transactions on the shareholder's behalf.

One important issue that arises in regard to the appointment of proxies relates to the proper interpretation of section 58(1) of the Companies Act 71 of 2008, namely whether this section, as read with section 58(3)(c) thereof, constitutes an unalterable provision giving a shareholder an unlimited right to appoint a proxy "at any time" before the proxy exercises the shareholder's rights at the shareholders' meeting, or whether the time period within which the proxy appointment must be submitted to the company may be limited by the Memorandum of Incorporation (hereafter the MOI). This issue was considered by the SCA in the Richard Du Plessis Barry case in view of the appellant's contention that the provisions of the $\mathrm{MOI}$ that limited the time period within which the instrument appointing a proxy must be delivered to the company or other person on behalf of the company were valid.

In this note, I examine the Richard Du Plessis Barry case with a focus on the proper interpretation of the right of a shareholder to appoint a proxy "at any time" as conferred by section 58(1) of the Companies Act 71 of 2008. I provide some critical comments on the main issues that this judgement raises, including the interpretation of section 58(1) in the context of "alterable" and "unalterable" provisions of the Companies Act 71 of 2008, a purposive interpretation of section 58(1), the interaction between section

Sections 58(2)(b)(i) and (ii) of the Companies Act 71 of 2008.

Stein and Everingham New Companies Act Unlocked 206.

Section 58(3)(a) of the Companies Act 71 of 2008.

Section 58(3) (b) of the Companies Act 71 of 2008.

Section 58(3) (c) of the Companies Act 71 of 2008. 
58(1) and section 58(3), the significance of the difference in the wording of section 58(1) of the Companies Act 71 of 2008 and section 189 of the Companies Act 61 of 1973 , as well as the practical implications of the court's decision in this matter. This is followed by a brief comparative analysis with selected international jurisdictions and some concluding remarks.

\section{Factual background}

\subsection{Facts as taken from the judgment of the SCA and court a quo}

The appellant was Richard Du Plessis Barry in his capacity as director of the first respondent, Clearwater Estates NPC (hereafter the Company). ${ }^{13}$ The second respondent was Mr Kevin Olivier in his capacity as the chairperson of the Company's board of directors. ${ }^{14}$ The appellant had brought an application before the Gauteng Division of the High Court (Pretoria) (hereafter the court a quo) in which he sought an order declaring certain resolutions relating to the internal governance of the Company, including a resolution approving an increase in levy payments, that were passed at a special general meeting, unlawful and void. ${ }^{15}$

The appellant had argued before the court a quo that the shareholder proxies that were delivered on the day of the meeting (but before the relevant resolutions were put to the vote) were invalid as they were submitted in contravention of articles 13.7.10 and 13.7.11 of the Company's MOI. ${ }^{16}$ Articles 13.7.10 and 13.7.11 provided that an instrument appointing a proxy had to be deposited at a specified place "not less than 48 (FORTY EIGHT) hours before the time appointed for the holding of the meeting" at which the proxy is to vote. Had these "late" proxies not been accepted, the meeting would not have met the quorum requirements as set out in the Company's $\mathrm{MOI}$ and the meeting would not have proceeded. ${ }^{17}$ The appellant had submitted before the court a quo that section 58(3) read conjunctively with section 58(1) of the Companies Act 71 of 2008, constituted an alterable provision. ${ }^{18}$ Therefore, according to the appellant's contentions, articles 13.7.10 and 13.7.11 of the Company's MOl could validly limit the period within which a proxy appointment must be submitted to a company or other person on behalf of a company.

\footnotetext{
13 Richard Du Plessis Barry case para 1.

$14 \quad$ Richard Du Plessis Barry case para 2.

15 See Du Plessis Barry v Clearwater Estates NPC (GP) (unreported) case number 82306/2014 of 13 November 2015.

$16 \quad$ Richard Du Plessis Barry case para 4.

17 Richard Du Plessis Barry case para 4.

18 See Du Plessis Barry v Clearwater Estates NPC (GP) (unreported) case number $82306 / 2014$ of 13 November 2015 para 21.
} 
On the other hand, the first and second respondents had submitted that section 58(1) of the Companies Act 71 of 2008, which gave a shareholder the right to appoint a proxy "at any time", constituted an unalterable provision. ${ }^{19}$ They had further argued that articles 13.7.10 and 13.7.11 of the Company's MOI were in contravention of section 58(1) and that these articles were, as a result, void in terms of section 15(1) of the Companies Act 71 of $2008 .^{20}$

\subsection{The decision of the court a quo}

The key issue in the matter before the court a quo related to whether articles 13.7.10 and 13.7.11 of the Company's MOI were lawful in view of section $58(1)$, which entitles a shareholder to appoint a proxy "at any time". ${ }^{21}$ Van der Westhuizen AJ rejected the appellant's submissions regarding the interpretation of section 58(3) and held that a "purposive and contextual interpretation" of section 58(1) as read with section 58(3) of the Companies Act 71 of 2008 made section $58(1)$ an unalterable provision. ${ }^{22}$ He held that if the appellant's submissions were to be upheld this would "result in an internal conflict within section 58 of the Act". ${ }^{23}$ Consequently, articles 13.7.10 and 13.7.11 of the Company's MOI were void. ${ }^{24}$ The acceptance of the late proxies at the Company's meeting was held to be in line with the provisions of section 58(1). Van der Westhuizen AJ therefore dismissed the application with costs and leave to appeal to the SCA was subsequently granted.

\subsection{The decision of the SCA}

The arguments before the SCA remained essentially the same as the arguments before the court a quo. The central issue was whether section 58(1) of the Companies Act 71 of 2008 is an unalterable provision giving a shareholder the right to appoint a proxy "at any time" before the proxy

19 See Du Plessis Barry v Clearwater Estates NPC (GP) (unreported) case number 82306/2014 of 13 November 2015 para 17.

20 See Du Plessis Barry v Clearwater Estates NPC (GP) (unreported) case number $82306 / 2014$ of 13 November 2015 paras 19-20. In terms of s 15(1) the provisions of a company's MOI must be consistent with the Companies Act 71 of 2008. Any provision of a company's MOI is void to the extent that it contravenes or is inconsistent with the Companies Act 71 of 2008, subject to s 6(15). Du Plessis Barry $v$ Clearwater Estates NPC (GP) (unreported) case number $82306 / 2014$ of 13 November 2015 paras 12, 13. Also see s 58(1) read with s 58(3)(c) of the Companies Act 71 of 2008. Du Plessis Barry $v$ Clearwater Estates NPC (GP) (unreported) case number 82306/2014 of 13 November 2015 para 27.

23 Du Plessis Barry v Clearwater Estates NPC (GP) (unreported) case number 82306/2014 of 13 November 2015 para 30.

24 Du Plessis Barry v Clearwater Estates NPC (GP) (unreported) case number $82306 / 2014$ of 13 November 2015 para 31. 
exercises the shareholder's rights at the shareholders' meeting, or whether the time period within which the instrument appointing the proxy must be delivered to the company (or to any person on behalf of the company) may lawfully be limited in the $\mathrm{MOI} .{ }^{25}$ Furthermore, the appellant sought to draw a distinction between sections 58(1) and 58(3)(c) of the Companies Act 71 of 2008 by arguing that the words "any time" in section 58(1) were only applicable to the giving of a proxy between the shareholder (the proxy giver) and the person whom the shareholder is appointing in terms of the proxy (the proxy receiver or proxyholder). ${ }^{26} \mathrm{He}$ also argued that for the purposes of regulating the procedures for the exercise of proxies (as opposed to the validity of the appointment of proxies), the Company was entitled to alter the "before" in section 58(3)(c) to the "not less than 48 (FORTY EIGHT) hours ... before" in its MOI. ${ }^{27}$ The effect of such a construction would be that a person could validly be appointed as a proxy but be unable to exercise the rights contained in such an appointment at a particular shareholders' meeting.

The SCA held that it was imperative to examine the provisions of sections 58 (1) (dealing with the appointment of a proxy) and 58(3)(c) (dealing with the exercise of the proxy) of the Companies Act 71 of 2008 together with articles 13.7.10 and 13.7.11 of the Company's MOI. ${ }^{28}$ Furthermore, the SCA determined that sections 58(1) and 58(3)(c) had to be considered in the context of the concepts of "alterable" and "unalterable" provisions, as defined in section 1 of the Companies Act 71 of $2008 .^{29}$ It affirmed the court a quo's conclusion that section $58(1)$ is an unalterable provision of the Companies Act 71 of 2008. It further held that the plain wording of section $58(1)$ as read with section $58(3)(c)$, with due regard to the context and purpose of these sections, is that a shareholder is entitled to appoint a proxy "at any time" to exercise that shareholder's rights at the shareholders' meeting. The only proviso is that the instrument appointing the proxy must be submitted to the company or to any person on behalf of the company before the proxy exercises the shareholder's rights at the particular shareholders' meeting. ${ }^{30}$ The SCA therefore concluded that the provisions of articles 13.7.10 and 13.7.11 of the Company's MOl which purported to limit the time period within which proxies must be submitted were inconsistent with section 58(1) and were, as such, void in terms of section

\footnotetext{
$25 \quad$ Richard Du Plessis Barry case paras 14, 15.

$26 \quad$ Richard Du Plessis Barry case para 14.

$27 \quad$ Richard Du Plessis Barry case para 14.

$28 \quad$ Richard Du Plessis Barry case para 9.

$29 \quad$ Richard Du Plessis Barry case para 11.

$30 \quad$ Richard Du Plessis Barry case para 18.
} 
15(1) of the Companies Act 71 of 2008. Having reached such a conclusion, the SCA dismissed the appeal with costs.

\section{Analysis}

The judgement of the SCA in the Richard Du Plessis Barry case raises important issues regarding the correct interpretation of section 58(1) as read with section 58(3)(c) of the Companies Act 71 of 2008, which merit further analysis. These issues include the interpretation of section 58(1) in the context of "alterable" and "unalterable" provisions of the Companies Act 71 of 2008, the purposive and contextual interpretation of section 58(1), the interaction between section 58(1) and section 58(3)(c), and (more fundamentally) the far-reaching practical implications that this judgement may have for companies and their shareholders.

\subsection{Interpretation of section 58(1) in the context of "alterable" and "unalterable" provisions of the Companies Act 71 of 2008}

Like the court a quo, the SCA's approach in the Richard Du Plessis Barry case was that the provisions of section 58(1) as read with section 58(3) (c) must be considered in the context of the distinction between "alterable" and "unalterable" provisions, as defined in section 1 of the Companies Act 71 of 2008. In terms of section 1 an "alterable provision" of the Companies Act 71 of 2008 is a provision "in which it is expressly contemplated that its effect on a particular company may be negated, restricted, limited, qualified, extended or otherwise altered in substance or effect by that company's Memorandum of Incorporation". Companies are at liberty to vary or alter the effect of such a provision in the $\mathrm{MOI}$, provided that the alteration is consistent with the Companies Act 71 of $2008 .^{31}$

In contrast, an "unalterable provision" is a provision of the Companies Act 71 of 2008 that "does not expressly contemplate that its effect on any particular company may be negated, restricted, limited, qualified, extended or otherwise altered in substance or effect by a company's Memorandum of Incorporation or Rules". 32 The significance of the distinction between these two definitions is that a company's MOI (or Rules) may not validly alter the substance of an unalterable provision. ${ }^{33}$ The only instance where a company may lawfully alter an unalterable provision in its $\mathrm{MOI}$ is where the alteration imposes "a higher standard, greater restriction, longer period of time or a more onerous requirement than would otherwise apply to the

31 See s 15(1)(a) and (b) of the Companies Act 71 of 2008.

32 Section 1 of the Companies Act 71 of 2008.

$33 \quad$ Richard Du Plessis Barry case para 12; s 15(2)(d) of the Companies Act 71 of 2008. Also see Stoop 2016 JCCL\&P 41-42 for an overview of the distinction between alterable and unalterable provisions. 
company in terms of an unalterable provision". ${ }^{34}$ More importantly, any provision of a company's MOI that is inconsistent with the Companies Act 71 of 2008 is void to the extent of its contravention of, or inconsistency with, this Act. ${ }^{35}$

In view of the definitions of, and the distinction between, "alterable" and "unalterable" provisions (as discussed above), the SCA confirmed the position taken by the court a quo that 58(1), providing the shareholders' right to appoint a proxy "at any time", constitutes an unalterable provision. ${ }^{36} \mathrm{It}$ found that this provision does not expressly contemplate that its effect may be altered by any company's MOI. ${ }^{37}$ It therefore followed that articles 13.7.10 and 13.7.11 of the Company's MOI, which contravened or were inconsistent with the unalterable provisions of section 58(1), were void in terms of section 15(1)(a) and (b) of the Companies Act 71 of 2008. The conclusion reached by both the court a quo and the SCA that section 58(1) is an unalterable provision of the Companies Act 71 of 2008 appears to be the correct one.

It is interesting to note that the SCA further held that unlike section 58(1), the provisions of 58(3)(c) of the Companies Act 71 of 2008, regulating the delivery of an instrument appointing a proxy, are alterable, as this section expressly contemplates that its effect may be altered by a company's MOI ${ }^{38}$ In my view, it is true from the plain wording of section 58(3)(c) that this section contemplates that its effect may be altered by a company in its $\mathrm{MOI}$. The section provides that "except to the extent that the Memorandum of Incorporation provides otherwise", an instrument appointing a proxy must be delivered to the company or other person on behalf of the company "before the proxy exercises any rights of the shareholder at a shareholders meeting". However, it is submitted that the practical significance of enacting section 58(3)(c) as an alterable provision is neither here nor there. It is difficult to see how this provision may be altered by a company's MOI in practice. Commenting on these difficulties, Professor Delport has stated as follows:

It would seem that the Memorandum of Incorporation can therefore only dispense with the lodging of the proxy, which would seem to be illogical as it would then be impossible to determine the quorum and also the voting results. Alternatively this provision could apparently also be interpreted that it can be lodged with someone other than the company or a person on behalf of the

Section 15(2)(a)(iii) of the Companies Act 71 of 2008.

Section 15(1)(a) and (b) of the Companies Act 71 of 2008.

Richard Du Plessis Barry case para 13.

Richard Du Plessis Barry case para 13.

Richard Du Plessis Barry case para 13. 
company ... Such interpretation would, it is submitted, be correct if the words 'on behalf of the company' did not appear in the subsection. ${ }^{39}$

It is submitted that the legislature should address this anomaly in the provisions of section 58 of the Companies Act 71 of 2008. One way of doing this would be to make paragraph (c) of section 58 (3) a stand-alone provision that is detached from section 58(3) so that the words "except to the extent that the Memorandum of Incorporation provides otherwise" would not apply to it. Nevertheless, what is of paramount significance is that even though section 58(3)(c) has been held to be an alterable provision, this does not affect the construction that section $58(1)$ is unalterable. ${ }^{40}$ This is so because section 58(3)(c) neither provides for any minimum time period for the submission of the instrument appointing a proxy nor allows any company to restrict the time period within which such an instrument must be submitted.

\subsection{Interaction between section 58(1) and 58(3)(c)}

The interaction between sections 58(1) and 58(3)(c) of the Companies Act 71 of 2008 is significant, particularly in view of the appellant's argument that there was a distinction between the appointment of a proxy in terms of section 58(1) and the exercise of a proxy in terms of section 58(3)(c) of the Companies Act 71 of 2008. The distinction which the appellant sought to draw in this regard was dismissed by the court as artificial, however ${ }^{41}$ The court held that the appointment of a proxy "at any time" as contemplated by section 58(1) is "not made in vacuo" but seeks to achieve its "statutorily defined" role of participating in, speaking and voting at a shareholders' meeting on behalf of the shareholder (the proxy giver). ${ }^{42}$ Imposing a time restriction under section 58(3)(c) of the Companies Act 71 of 2008 within which the instrument appointing the proxy must be delivered would, according to the court, not only quash these statutorily defined purposes but it would also challenge the validity of the appointment of the proxy as:

[t]he appointment of a proxy who is unable to perform any of these statutorily defined functions at a particular meeting has no purpose and is no appointment at all. ${ }^{43}$

Accordingly, when interpreting sections $58(1)$ and $58(3)(c)$ of the Companies Act 71 of 2008, the purpose which these provisions seek to serve should be considered, amongst other factors. ${ }^{44}$ Whereas section

$39 \quad$ Delport Henochsberg 228.

$40 \quad$ Richard Du Plessis Barry case para 13.

$41 \quad$ Richard Du Plessis Barry case para 16.

42 Section 58(1)(a) of the Companies Act 71 of 2008; Richard Du Plessis Barry case para 16.

$43 \quad$ Richard Du Plessis Barry case para 16.

$44 \quad$ Richard Du Plessis Barry case para 17; and Natal Joint Municipal Pension Fund v Endumeni Municipality [2012] ZASCA 13 (16 March 2012) referred to therein. 
58(1) entitles a shareholder to appoint a proxy "at any time" for the purpose of exercising that shareholder's rights at the shareholders' meeting, section $58(3)(c)$ is the only proviso to the former section requiring that the instrument appointing the proxy must be submitted (to the company or to any person on behalf of the company) before the proxy exercises the shareholder's rights at the particular shareholders' meeting. ${ }^{45}$ The latter provision, therefore, does not authorise any company to restrict the time period for the submission of the instrument of a proxy's appointment.

\subsection{The significance of the difference in the wording of section 58(1) of the Companies Act 71 of 2008 and section 189 of the Companies Act 61 of 1973}

Section 58 of the Companies Act 71 of 2008 is the equivalent of section 189 of the Companies Act 61 of 1973, but there are significant differences between these two provisions. ${ }^{46}$ Unlike its predecessor, section 58 of the Companies Act 71 of 2008 generally provides for a much improved proxy system in a bid to enhance shareholder protection and corporate governance. ${ }^{47}$ Section $189(1)$ of the Companies Act 61 of 1973 (the enabling provision and the equivalent of section 58(1) of the Companies Act 71 of 2008) provided as follows:

Any member of a company entitled to attend and vote at a meeting of the company, or where the articles of a company limited by guarantee so provide, any member of such company, shall be entitled to appoint another person (whether a member or not) as his proxy to attend, speak, and vote in his stead at any meeting of the company: Provided that, unless the articles otherwise provide, a proxy shall not be entitled to vote except on a poll and a member of a private company shall not be entitled to appoint more than one proxy.

Section 189(3) then regulated the exercise of the proxy. It provided that:

(a) Any provision contained in a company's articles shall be void in so far as it would have the effect of requiring the instrument appointing a proxy, or any other document necessary to show the validity of or otherwise relating to the appointment of a proxy, to be received by the company at its registered office or by any other person more than forty-eight hours before a meeting in order that the appointment may be effective thereat.

(b) In determining any period for the purposes of this subsection Saturdays,

Sundays and public holidays shall not be taken into account.

In the Richard Du Plessis Barry case the court observed that under section 189(3)(a) of the Companies Act 61 of 1973, a clause in a company's articles

Richard Du Plessis Barry case para 18.

Stein and Everingham New Companies Act Unlocked 205.

For example, a shareholder of a private company is no longer prohibited from appointing more than one proxy and a proxy is no longer prohibited from voting on a show of hands. See generally Cassim et al Contemporary Company Law 365-367. 
specifying a longer period for the submission of the instrument appointing a proxy than 48 hours prior to the meeting would be void and the proxy would not be "effective" at the meeting. ${ }^{48}$ However, a provision such as article 13.7.10 of the Company's MOI specifying a minimum period of not less than 48 hours prior to the meeting would be valid. ${ }^{49}$ The court's observations are correct, other than that I respectfully disagree with the court's view that the proxy would not be effective at the meeting. ${ }^{50}$ Notably, the court stated this view in the following terms:

\section{In terms of [section 189(3) of] the 1973 Act, a provision in a company's articles that the instrument appointing a proxy had to be received by the company more than 48 hours before the meeting, would be void and the proxy would not be 'effective' at the meeting. ${ }^{51}$}

It can be argued that, since the provision in a company's articles would be null and void, a proxy rendered "late" by such an invalid time restriction in the articles would be effective at the meeting as long as it was received before the meeting. In other words, a time restriction that is null and void would have no effect on the validity of a proxy that was submitted in compliance with section 189(3) of the Companies Act 61 of 1973.

The court correctly noted, however, that although section 189 of the Companies Act 61 of 1973 did not specify a time period for the appointment of a proxy, it restricted a shareholder's ability to appoint a proxy less than 48 hours prior to the meeting where a company's articles contained such a provision. ${ }^{52}$ In such circumstances, the appointment of a proxy within the 48 hours preceding the meeting would be "an exercise in futility as the proxy could not be exercised at that meeting". ${ }^{53}$ It found that section 58 of the Companies Act 71 of 2008 differs strikingly from such an approach as it does not limit a shareholder's ability to appoint a proxy less than 48 hours before the meeting. Instead, section 58(1) provides that a proxy may be appointed "at any time". The SCA held that the use of the phrase "at any time" in section 58(1), which did not appear in its predecessor, amounted to a "deliberate change of expression" which prima facie revealed a change in the legislative purpose of the provision. ${ }^{54}$

Richard Du Plessis Barry case para 20.

Richard Du Plessis Barry case para 20.

Richard Du Plessis Barry case para 20.

Richard Du Plessis Barry case para 20.

Richard Du Plessis Barry case para 20.

Richard Du Plessis Barry case para 20.

54 See $R v$ Shole 19604 SA 781 (A) 787; and Natal Joint Municipal Pension Fund $v$ Endumeni Municipality [2012] ZASCA 13 (16 March 2012) paras 20-26, referred to in the Richard Du Plessis Barry case para 21. 
The SCA further considered the deliberate change in expression in section $58(1)$ in the light of the provisions of section 58(3)(c) of the Companies Act 71 of 2008. It found that, unlike section 189 of the Companies Act 61 of 1973 which provided for a minimum period of no more than 48 hours for the delivery of the instrument appointing a proxy, section 58(3)(c) of the Companies Act 71 of 2008 does not specify a minimum time period for the delivery of the instrument of a proxy's appointment. Instead, section 58(3) (c) merely requires that such an instrument must be delivered "before" the proxy exercises the shareholder's rights at the specific shareholders' meeting. This, according to the SCA, signified "a change of legislative purpose" in relation to the minimum period of no more than 48 hours provided for under the old Companies Act 61 of $1973 .{ }^{55}$ Therefore, the current provisions of section 58(1) should be interpreted in this context.

\subsection{The practical implications of the judgement}

The Richard Du Plessis Barry case has some significant implications for companies and shareholders as far as the convening of shareholders' meetings is concerned. First, there is a long-standing practice, both in South Africa and in most other modern jurisdictions, of prescribing a time period in the $\mathrm{MOI}$ for the submission of proxies. ${ }^{56}$ The effect of this long-standing practice has been to invalidate and to preclude proxies that were submitted after the prescribed deadline from participating at the shareholders' meeting. In view of the SCA's judgment in Richard Du Plessis Barry, this practice has to change. The relevant provisions in the MOI invalidating "late" proxies are void and, as such, will have to be amended to reflect the unalterable provisions of section $58(1)$ as read with section 58(3)(c) of the Companies Act 71 of 2008, namely that the instrument appointing a proxy may be submitted at any time before the proxy exercises the shareholder's rights at the meeting. It is interesting to note that there are some companies that have already sought shareholder approval to amend the provisions of their $\mathrm{MOI}$ that were similar to articles 13.7 .10 and 13.7.11 in this case in

$55 \quad$ Richard Du Plessis Barry case para 21.

56 See s 189(3) of the Companies Act 61 of 1973; s 372(5) of the UK Companies Act, 1985; s 327 of the UK Companies Act, 2006; s 250B of the Australian Corporations Act, 2001; clause 6(5) of Schedule 1 of the New Zealand Companies Act, 1993; s 301 of the Kenyan Companies Act, 2015; s 301(5) of the Canada Business Corporations Act,1985; and s 105(4) of the Indian Companies Act, 2013. Also see Cassim et al Contemporary Company Law 365, where the learned authors observe that it was common practice for most articles of association under the Companies Act 61 of 1973 to impose a deadline of 48 hours prior to the meeting for the submission of the instrument appointing a proxy. The purpose of this practice was, according to the learned authors, to provide an opportunity for the proxies to be scrutinised before they were exercised at the meeting. This practice has continued under the Companies Act 71 of 2008 despite the fact that this specific Act has not allowed companies to specify such a minimum time period. 
order to align them with the correct interpretation of sections 58(1) and $58(3)(c)$ that the instrument appointing a proxy may be submitted at any time before the proxy exercises the shareholder's rights at the meeting. ${ }^{57}$

Secondly, the SCA's decision in the Richard Du Plessis Barry case may give rise to practical challenges in the conducting of shareholders' meetings. These practical difficulties are evident from the appellant's submission to the effect that an unalterable right to appoint a proxy "at any time", including on the day of the meeting, would make shareholders' meetings unworkable, especially in big companies with numerous shareholders. ${ }^{58}$ The submission of a large number of proxies on the day of the meeting, a few moments before the meeting or even during the meeting (that is, before the proxy exercises any rights of the shareholder) may cause undue delays, inconveniences or disruption of shareholders' meetings. These practical

57 See, for example, special resolution number five that was tabled for shareholder approval at Super Group Limited's annual general meeting (hereafter AGM) on 28 November 2017. The resolution was phrased as follows:

"RESOLVED THAT paragraph 33.4.2 of the company's MOI hereby be amended to accord with the decision of the Supreme Court of Appeal on 13 April 2017 in the case of Richard du Plessis Barry v Clearwater Estates NPC \& Others (187/2017) ZASCA11.

Accordingly, the special resolution provides as follows:

5.1 The existing paragraph 33.4 .2 is deleted, immediately upon this special resolution being registered.

5.2 A new paragraph 33.4.2 is to replace the deleted paragraph 33.4 .2 to provide that:

Shareholders are requested to lodge completed Forms of Proxy to reach the Transfer Secretaries by no later than 24 hours prior to the commencement of the Annual General Meeting or General Meeting or Special General Meeting. Nevertheless, completed Forms of Proxy may be lodged with the chairperson of the Annual General Meeting or General Meeting or Special General Meeting prior to the Annual General Meeting or General Meeting or Special General Meeting so as to reach the chairperson prior to the commencement of voting on the resolutions to be tabled at the Annual General Meeting or General Meeting or Special General Meeting."

See Super Group Limited 2017 http://supergroup.co.za/ 2017_integrated_report/downloads/supergroup_agm.pdf 5. Also see special resolution number three that was tabled at Cashbuild Limited's AGM on 27 November 2017, which was phrased as follows:

"TO RESOLVE to amend article 10.1.2 of the Company's Memorandum of Incorporation, to align with the decision of the Supreme Court of Appeal on 13 April 2017 in the case of Richard du Plessis Barry v Clearwater Estates NPC \& Others (187/2016)[2017] ZASCA11 Accordingly, the Special Resolution provides as follows: 11.1 The existing article 10.1.2 (including sub-points 10.1.2.1 and 10.1.2.20) are deleted, immediately upon this Special Resolution being registered.

11.2 A new article 10.1.2 is to replace the deleted article 10.1.2 to provide that:

Proxy forms shall be lodged with the Transfer Secretaries or with the Chairman of the Company and shall thereupon immediately become valid at any time before voting commences."

See Cashbuild Limited 2017 http://www.cashbuild.co.za/Reports/2017/ Tabs/notice_of_annual_general_meeting.pdf 141 . 
challenges may be further exacerbated by the statutory requirements for the verification and validation of proxies by the person presiding at the meeting before the proxy may participate at the shareholders' meeting. ${ }^{59}$ The person presiding over the meeting would surely require a reasonable opportunity to scrutinise, verify and validate the proxies before the start of the particular meeting. The SCA in the Richard Du Plessis Barry case took the view that in the event that the above concerns are valid, these practical challenges should appropriately be addressed by "legislative intervention" and not by a "strained interpretation" of the Companies Act 71 of $2008 .{ }^{60}$

I have already indicated that I agree with the SCA's reasoning that section 58(1) of the Companies Act 71 of 2008, as it is currently worded, is an unalterable provision conferring a right to appoint a proxy "at any time", even a few moments before the proxy exercises the shareholder's rights at the shareholders meeting. I also agree that an amendment of section 58 of the Companies Act 71 of 2008 would be necessary to resolve the practical challenges that the current legal position may present in regard to the conduct of shareholders' meetings. In the discussion below, I consider whether an unalterable right to appoint a proxy "at any time" is warranted in view of these practical challenges and the different approach adopted by comparable foreign jurisdictions in this regard.

\subsection{Comparative analysis}

In this part, I discuss the provisions of sections 58(1) and 58(3)(c) of the Companies Act 71 of 2008 in the light of the equivalent provisions in selected comparable jurisdictions, namely the United Kingdom (hereafter the UK), Australia, New Zealand, Kenya, Canada and India. A brief comparative analysis with these international jurisdictions is motivated by relevance, as representation by proxy is a matter that is also regulated in the company law statutes of each of the selected jurisdictions. ${ }^{61}$ In addition, jurisdictions such as Kenya and India have recently reformed their companies legislation and, it is submitted, there are important lessons that may be learnt from the approach adopted by these jurisdictions. So, in a

59 See the appellant's contention in the Richard Du Plessis Barry case para 22 and $\mathrm{s}$ 63(1)(b) of the Companies Act 71 of 2008.

$60 \quad$ Richard Du Plessis Barry case para 22.

61 The Department of Trade and Industry (DTI) Policy Paper of 2004 expressly stated that it was essential for South African company law to be harmonised with the company laws of international jurisdictions, where appropriate, in view of the involvement of South Africa and international jurisdictions in international trade and investment. See GN 1183 in GG 26493 of 23 June 2004. It should also be pointed out that most of the provisions and principles of the Companies Act of 2008 are traceable to the equivalent legislation in jurisdictions such as Australia, New Zealand, Canada and the UK. See, in this regard, Du Plessis and Mathiopoulos 2016 Aust Jnl of Corp Law 305. 
nutshell, the object of a comparative analysis is to establish whether the relevant legislation in comparable jurisdictions provides for an unrestricted right to appoint a proxy "at any time" as section 58(1) of the Companies Act 71 of 2008 does, as well as whether the legislation in comparable jurisdictions allows companies to specify a minimum time period for the submission of documents for a proxy's appointment. If companies are given the flexibility to specify such a time period, it would be interesting to analyse the underlying philosophical rational for such an approach and to see whether it would equally apply to South Africa.

\subsubsection{The UK}

Section 324 of the UK Companies Act 2006 (the enabling provision in the UK) gives any member the right to appoint a proxy to exercise all or any of his rights to attend, speak and vote at a company's meeting. Unlike section 58(1) of the Companies Act 71 of 2008, section 324 of the UK Companies Act 2006 does not give a shareholder the right to appoint a proxy "at any time".

However, section 327 of the UK Companies Act 2006 specifically regulates the notice of appointment of a proxy. In terms of section 327(1) read with section 327(2), any provision of the company's articles that has the effect of requiring that the appointment of a proxy or any document showing the validity of the appointment of a proxy be received by the company or another person earlier than the time period set out in the provision shall be void to that extent. In the case of a meeting or adjourned meeting, a provision of the articles would be invalid if it requires the appointment to be submitted to the company or other person earlier than 48 hours before the time for the meeting or adjourned meeting. ${ }^{62}$ Where a poll is taken more than 48 hours after it was demanded, the articles may not require that a proxy be submitted earlier than 24 hours before the scheduled time for the taking of the poll. ${ }^{63}$ Where a poll is taken not more than 48 hours after it was demanded, the articles may not require that a proxy be submitted earlier than the time at which the poll was demanded. ${ }^{64}$ Only working days are taken into account when determining the periods mentioned above. ${ }^{65}$ Therefore, companies that are subject to the UK Companies Act 2006 would be free to prescribe

62 Section $327(2)(a)$ of the UK Companies Act, 2006. This provision is similar to $\mathrm{s}$ 372(5) of the old UK Companies Act, 1985.

Section 327(2)(b) of the UK Companies Act, 2006. Note that this provision never existed under the UK Companies Act, 1985.

64 Section 327(2)(c) of the UK Companies Act, 2006. Again, this is a new provision which did not exist under the UK Companies Act, 1985.

65 Section 327(3) of the UK Companies Act, 2006. 
a notice period for the appointment of a proxy as long as such a period is not earlier than the periods specified above.

\subsubsection{Australia}

In Australia, section 249X of the Corporations Act 2001 (the enabling provision) gives a member who is entitled to attend and vote at a members' meeting a right to appoint a proxy to exercise that member's rights at the meeting. Like its equivalent provision in the UK, ${ }^{66}$ section $249 \mathrm{X}$ of the Corporations Act 2001 is different from section 58(1) of the Companies Act 71 of 2008 in that it is silent on the time period for the appointment of a proxy and does not contain the words "at any time". It is also noteworthy that section 250A of the Corporations Act 2001, providing for the appointment and validity of a proxy, also does not specify any time period.

Section 250B of the Corporations Act 2001 is, indeed, a separate section that provides for the time period within which the documents appointing a proxy must be received by the company. It provides that for an appointment of a proxy to be effective, the documents appointing the proxy must be received by the company at least 48 hours before the meeting. ${ }^{67}$ Where a members' meeting has been adjourned, the documents must be received by the company at least 48 hours before the resumption of the meeting. ${ }^{68} \mathrm{~A}$ notable feature of the Corporations Act 2001 is that it defines what constitutes "receipt of documents" for the purposes of the appointment of a proxy. ${ }^{69}$

Notwithstanding the above provisions, the Corporations Act 2001 gives a company the flexibility to reduce the 48 hours referred to above in the company's constitution or in the notice of meeting. ${ }^{70}$ This flexibility is somewhat similar to the approach in the UK where a company may provide for any time period for the submission of the documents appointing a proxy in its articles, as long as such a period is not earlier than the minimum time periods prescribed in section 327 of the UK Companies Act 2006. As an example, a provision in a company's constitution or notice of meeting that prescribes a notice period (for the submission of proxies) of no later than 24

66 See s 324 of the UK Companies Act, 2006.

67 Section 250B(1) of the Corporations Act, 2001.

68 Section 250B(2) of the Corporations Act, 2001.

69 Section $250 \mathrm{~B}(3)$ of the Corporations Act, 2001 provides, in this regard, that a company receives a document appointing a proxy when the document is received at the company's registered office; or at a fax number at the company's registered office; or at a place, fax number or electronic address specified for such a purpose in the notice of meeting. Where the notice of meeting specifies other electronic means for giving the document, the company receives a document given by such means as prescribed by the regulations. Section 250B(5) of the Corporations Act, 2001. 
hours prior to the start of the meeting would be valid in Australia. In contrast, a notice period of no later than 72 hours prior to the start of the meeting would be invalid.

\subsubsection{New Zealand}

Clauses 6(1) to (3) of Schedule 1 to the Companies Act 1993 of New Zealand, regulating the appointment of a proxy by a shareholder, do not prescribe a time period for the appointment of a proxy and they do not contain the words "at any time" that are found in section 58(1) of the Companies Act 71 of 2008. Moreover, the Companies Act 1993 of New Zealand is drafted along the same lines as the Corporations Act 2001 of Australia in so far as the deadline for the submission of proxies is concerned. Clause 6(4) of Schedule 1 to the Companies Act 1993 requires that a copy of the notice of the appointment of a proxy be produced prior to the start of the meeting for the proxy to be valid. However, the legislation allows the company to specify a time period within which the notice of appointment must be produced, provided that such a specified time period is not earlier than 48 hours before the commencement of the meeting. ${ }^{71} \mathrm{In}$ New Zealand, therefore, the instrument of a proxy's appointment must be produced either before the start of the meeting or by the time specified in the company's constitution provided that, in the latter case, the specified time is not earlier than 48 hours before the start of the meeting. In addition, clause 6(6) of Schedule 1 to the Companies Act 1993 gives companies the flexibility to provide for different matters for different kinds of proxies, including a different specified time period for the production of a proxy by electronic means. As in Australia and in the UK (save for situations where a poll is demanded in the UK), the default position in New Zealand is that the stipulated period for the production of proxies must not be earlier than 48 hours before the start of the meeting. Companies are then given the liberty to provide for a time period within which proxies must be submitted as long as it is not earlier than 48 hours prior to the start of the meeting.

\subsubsection{Other jurisdictions}

As in the UK, Australia and New Zealand, other modern jurisdictions such as Kenya, Canada and India give shareholders the right to appoint a proxy to exercise the particular shareholder's right at a shareholders' meeting, but do not entitle the shareholder to appoint a proxy "at any time". ${ }^{72}$ As far as

71 Clause 6(5) of Schedule 1 of the Companies Act, 1993.

72 See s 101 of the Indian Companies Act, 2013; s 298(1) of the Kenyan Companies Act, 2015, which is a replica of s 324(1) of the UK Companies Act, 2006; and s 148(1) of the Canada Business Corporations Act, 1985. A notable weakness of $s 105$ of the Indian Companies Act, 2013, when compared with its counterparts, is that it gives proxies very limited rights. For example, s 105(1) of the Indian Companies Act, 2013 
the period within which a notice of appointment of a proxy is to be given to the company, section 301 of the Kenyan Companies Act 2015 is a replica of section 327 of the UK Companies Act 2006. ${ }^{73}$ It provides that a company's articles are void to the extent that they would have the effect of requiring the appointment of a proxy or any document showing the validity of the appointment of a proxy to be received by the company or another person earlier than the time period set out in the provision. In the case of a meeting or adjourned meeting, a provision of the articles would be void to the extent that it requires the appointment to be submitted to the company or other person earlier than 48 hours prior to the time for holding the meeting or adjourned meeting. ${ }^{74}$ Where a poll is taken more than 48 hours after it was demanded, a provision in the articles will be void if it requires that a proxy be submitted earlier than 24 hours before the scheduled time for the taking of the poll. ${ }^{75}$ If a poll is taken not more than 48 hours after it was demanded, a provision in the articles will be void to the extent that it requires that a proxy be submitted earlier than the time at which the poll was demanded. ${ }^{76}$ As is the case in the UK, only working days are taken into account when calculating the above periods. ${ }^{77}$

Similarly, section 148(5) of the Canada Business Corporations Act 1985 provides that a notice of a shareholders' meeting may specify a time not more than 48 hours prior to the meeting or adjournment, before which time proxies must be deposited with the company or its representative. Saturdays and holidays are disregarded when determining such time. ${ }^{78}$

Section 105(4) of the Companies Act 2013 of India provides that a provision in a company's articles that requires a period longer than 48 hours before a meeting for depositing any instrument appointing a proxy will have effect as if a period of 48 hours had been required by such a provision. The same consequence would apply to a provision in respect to any other document required to show the validity of a proxy's appointment so that the appointment may be effective at the particular meeting. ${ }^{79}$ It appears from the wording of section 105(4) of the Companies Act 2013 that such an instrument appointing a proxy should be submitted either to the company or to any other person.

does not allow a proxy to speak at a shareholders' meeting and the proxy is also not entitled to vote except on a poll.

73 See para 3.5.1 above for a discussion of s 327 of the UK Companies Act, 2006.

74 Section 301(2) (a) of the Companies Act, 2015.

75 Section 301(2)(b) of the Companies Act, 2015.

76 Section 301(2) (c) of the Companies Act, 2015.

77 Section 301(3) of the Companies Act, 2015.

78 Section 148(5) of the Canada Business Corporations Act, 1985.

79 Section 105(4) of the Companies Act, 2013. 
From the foregoing discussion of the provisions in comparable jurisdictions, two notable differences between the provisions of section 58 of the Companies Act 71 of 2008 and its equivalent provisions in the jurisdictions discussed above immediately come to light. The first notable difference is that, unlike section 58(1) of the Companies Act 71 of 2008, the equivalent provisions in the jurisdictions discussed above do not give shareholders the right to appoint a proxy "at any time". ${ }^{80}$ The provisions of section $58(1)$ of the Companies Act 71 of 2008 are, therefore, unique and are out of step with the trend in other modern jurisdictions in so far as they explicitly entitle a shareholder to appoint a proxy "at any time".

The second notable difference is that section 58(3) (c) of the Companies Act 71 of 2008 neither specifies the period within which the instrument appointing a proxy must be submitted to the company (or other representative of the company) nor allows any company in its $\mathrm{MOI}$ or notice of meeting to limit the time period within which a proxy may be appointed. Instead, the section merely requires that the instrument appointing a proxy must be submitted to the company or to any person on behalf of the company before the proxy exercises the shareholder's rights at the particular shareholders' meeting. ${ }^{81}$ On the other hand, the equivalent provisions in the selected comparable jurisdictions allow companies to specify a minimum time period within which a notice of the appointment of a proxy is to be given to the company. This period in these jurisdictions must not be more than 48 hours prior to the start of the relevant shareholders' meeting or adjournment. Companies that are subject to the laws of these jurisdictions may, therefore, validly provide in their constitutions or notice of meetings that the documents appointing a proxy must be submitted no later than 48 hours prior to the meeting, as was the case with articles 13.7.10 and 13.7.11 in the Richard Du Plessis Barry case. Companies are also permitted to provide for a shorter time period.

The underpinning philosophical rationale for the position adopted by the identified comparable foreign jurisdictions (that is, to allow companies to limit the time period within which the instrument appointing a proxy must be submitted in their constitutions or notice of meeting) is presumably to allow

80 See s 324 of the UK Companies Act, 2006; s 249X of the Corporations Act, 2001; clauses 6(1) to (3) of Schedule 1 of the New Zealand Companies Act, 1993; s 101 of the Indian Companies Act, 2013; s 298(1) of the Kenyan Companies Act, 2015; and s 148(1) of the Canada Business Corporations Act, 1985.

81 It is, therefore, clear that under s 58(1) as read with s 58(3)(c) of the Companies Act 71 of 2008 a shareholder has the right to appoint a proxy "at any time" to exercise that shareholder's rights at the shareholders' meeting with the only proviso that the instrument appointing the proxy must be submitted to the company or to any person on behalf of the company before the proxy exercises the shareholder's rights at the meeting. See Richard Du Plessis Barry case para 18. 
a reasonable opportunity for the proper administration of proxies before they are exercised at the meeting and to prevent undue delays, inconveniences or disruptions of shareholders' meetings which may be caused by the delivery and handling of proxies within a short period prior to the meeting or even at the meeting. ${ }^{82}$

The question, therefore, is whether the South African legislature has taken a positive trend-setting trajectory in including the words "at any time" in section 58(1) and in enacting section 58(3)(c) of the Companies Act 71 of 2008, or whether the approach taken by the South African legislature in this regard is flawed, inconsistent with the trend in other modern jurisdictions, and would probably lead to undue difficulties in practice. There can be no doubt that in drafting these provisions the South African legislature was motivated by considerations of creating flexibility and promoting shareholder activism. ${ }^{83}$ It can be argued that the right to appoint a proxy is key to the exercise of other shareholder governance rights such as the shareholders' rights to vote, to speak at, and to participate in shareholders' meetings. It has been noted that in practice a significant number of shareholders do not attend meetings. ${ }^{84}$ Therefore, it is arguable that to encourage shareholder activism and participation in the governance of companies, it is important that the shareholders' rights to vote and to participate in shareholders' meetings should remain as unencumbered as possible. The provisions of sections 58(1) and 58(3)(c) of the Companies Act 71 of 2008 can thus be viewed as a deliberate departure by the legislature from the equivalent provisions of section 189 of the Companies Act 61 of $1973 .{ }^{85}$ In making section 58(1) as read with section 58(3)(c) of the Companies Act 71 of 2008 an unalterable provision, the legislature appears to have placed more weight on the considerations of promoting shareholder activism than on the practical concerns that it may create. However, it does not appear that the legislature anticipated the magnitude of the administrative difficulties that these provisions may cause for companies in practice, especially in the context of large companies with a large number of dispersed shareholders. ${ }^{86}$ It is imperative that an appropriate balance be struck between the key objectives of the Companies Act 71 of 2008 in this regard, for example between the promotion of flexibility

\footnotetext{
$82 \quad$ Cassim et al Contemporary Company Law 365.

83 See Du Plessis Barry v Clearwater Estates NPC (GP) (unreported) case number $82306 / 2014$ of 13 November 2015 para 26.

84 Cassim et al Contemporary Company Law 365.

85 Richard Du Plessis Barry case paras 17, 18.

86 See para 3.4 above for a discussion of these practical difficulties.
} 
and shareholder activism ${ }^{87}$ on the one hand and the encouragement of efficiency on the other. ${ }^{88}$

It is also notable that the draft Companies Amendment Bill 2018, published by the DTI for public comment on 21 September 2018, does not address the issue of representation by proxy. ${ }^{89}$ This Bill does not propose any amendments regarding the issue of the appointment of proxies "at any time" in terms of section 58(1) of the Companies Act 71 of 2008.

It is therefore submitted that the legislature should consider the practical difficulties highlighted in the Richard Du Plessis Barry case. Should the legislature be satisfied that these difficulties are "real and not simply apparent", 90 it should amend section 58 of the Companies Act 71 of 2008 to address them. In such an event, it is submitted that it would be imperative also to consider the approach adopted by the foreign jurisdictions discussed above. Section 58 of the Companies Act 71 of 2008 could therefore be amended to provide that the instrument appointing a proxy must be submitted to the company or any other person on behalf of the company before the proxy exercises the particular shareholder's rights at the meeting or by the time specified in the company's MOl or notice of meeting, provided that such a specified time is not earlier than 48 hours before the start of the meeting or adjourned meeting. ${ }^{91}$ Only business days should be considered when determining the time period for the submission of proxies. ${ }^{92}$ The Companies Act 71 of 2008 should further provide that any provision in a company's $\mathrm{MOI}$ or notice of meeting requiring a period longer than the time periods suggested above for depositing the instrument appointing a proxy will have effect as if the periods suggested above had been required by such a provision. ${ }^{93}$ This would create certainty that the proxy would be effective at the meeting, notwithstanding a provision of a $\mathrm{MOI}$ or notice of meeting that specifies an invalid time period.

It is submitted that the suggested approach would not be inflexible as it would also afford companies the flexibility to reduce the maximum notice period of 48 hours in the $\mathrm{MOl}$ or notice of meeting. It would also be possible to deliver an instrument appointing a proxy before the commencement of voting on the resolutions at the meeting if the $\mathrm{MOI}$ or notice of meeting does not specify a time period for the delivery of such instrument. The suggested approach also does not negate shareholder activism. Shareholder activism

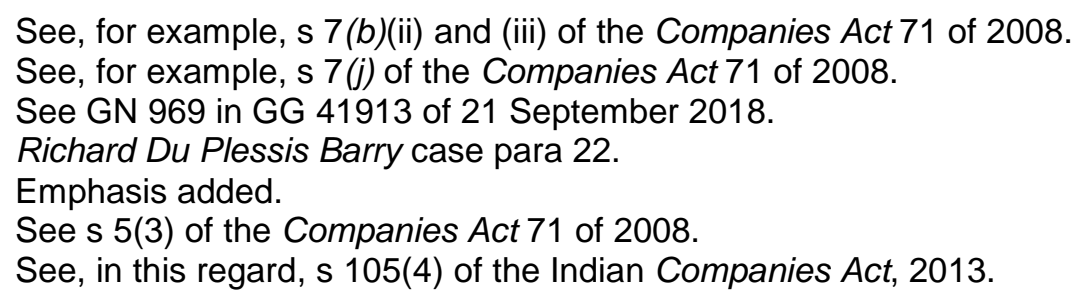


can still be promoted through other existing and progressive provisions of the Companies Act 71 of 2008 in this regard, for example, giving proxies extensive rights to represent shareholders at the meeting ${ }^{94}$ as well as a minimum notice period of fifteen business days for general meetings of public companies and non-profit companies (ten business days for other companies), which gives shareholders a reasonable amount of time to prepare for the meeting, including the submission of proxies. ${ }^{95}$ Should the legislature decide to amend the Companies Act 71 of 2008 in the manner suggested above, it would also be imperative to amend section 58(1) to remove the words "at any time" in order to avoid an internal conflict in section 58 of the Companies Act 71 of 2008 . The suggested amendments would align the provisions of section 58 of the Companies Act 71 of 2008 with international trends and would resolve the practical challenges and unintended consequences associated with an unqualified right to appoint a proxy at any time, including a few moments before the proxy exercises the shareholder's rights at the meeting.

It is also suggested that, in the meantime, companies should find ways to mitigate the practical challenges associated with the submission of a large number of proxies at the meeting but should do so without violating the provisions of section 58(1) and (3) of the Companies Act 71 of 2008. One way of doing so would be to provide in the MOI or notice of a shareholders' meeting that, for the purposes of administering the proxies efficiently, a shareholder who wants to be represented by a proxy should ensure that the instrument by which the proxy is appointed is delivered to the company by no later than a specified time before the start of the meeting. Such a time limit could be 48 hours, or even 24 hours, before the start of the meeting. Companies should make it clear in the MOl or notice of meeting, however, that adherence to such a time limit is encouraged for administrative purposes only, and that proxy instruments delivered later than such specified time period, including those delivered at the relevant meeting, will be accepted.

In a potentially positive development, on 22 November 2017 South Africa's central securities depository, Strate (Pty) Ltd, and Nasdaq announced the conclusion of their agreement intended to introduce and develop an electronic voting (e-voting) platform based on the block-chain technology in the South African capital markets. ${ }^{96}$ It is anticipated that the e-voting system,

94 These are remarkable improvements from s 189 of the Companies Act 61 of 1973 , which, for example, prohibited (unless the articles provided otherwise) a proxy from voting except on a poll, and shareholders of private companies from appointing more than one proxy. See generally Cassim et al Contemporary Company Law 365-367.

95 See s 62(1) of the Companies Act 71 of 2008.

96 Strate 2017 https://www.strate.co.za/blog/2017/11/nasdaq-to-deliver-blockchain-evoting-solution-to-strate/. 
if successfully implemented, would, among other things, improve efficiency and transparency in the appointment of proxies, including the submission, verification and processing of proxy instruments as well as proxy votes at shareholders' meetings of listed companies. ${ }^{97}$ This would simplify the current administration-intensive proxy voting system for listed companies. It is also expected that the e-voting system and the block-chain technology would make it possible for shareholders of listed companies who are unable to attend general meetings in person to vote from wherever they are. ${ }^{98}$ To an extent, a successful implementation of such a system could be viewed as rendering it unnecessary for shareholders who are unable to attend general meetings in person to appoint proxies. However, in my view the evoting system and the block-chain technology would not completely do away with the need to appoint proxies, particularly in the context of shareholders who do not have the capacity and expertise to deal with certain governance matters and complex corporate transactions that may be considered at shareholders meetings. Moreover, the effectiveness of a system such as e-voting, in so far as the appointment of proxies and proxy voting are concerned, would depend among other things on the successful implementation and widespread accessibility of the system to companies, shareholders and proxies.

\section{Conclusion}

In this note I have analysed the judgement of the SCA in the Richard Du Plessis Barry case regarding the proper interpretation of the right of a shareholder to appoint a proxy "at any time" as conferred by section 58(1) of the Companies Act 71 of 2008. I have highlighted the main issues that this judgement raises, including the interpretation of section 58(1) in the context of "alterable" and "unalterable" provisions of the Companies Act 71 of 2008, a purposive interpretation of section $58(1)$, the interaction between section 58(1) and section 58(3), the significance of the difference in the wording of section 58(1) of the Companies Act 71 of 2008 and section 189 of the Companies Act 61 of 1973 , as well as the practical implications of the SCA's decision in this matter. I concur with the conclusion reached by both the court a quo and the SCA that in terms of the current section 58(1) as read with section 58(3)(c) of the Companies Act 71 of 2008 a shareholder is entitled to appoint a proxy "at any time" to exercise that shareholder's rights at the shareholders meeting and that the only proviso to this "unalterable" provision is that the instrument appointing the proxy must be submitted to the company or to any person on behalf of the company before

97 Strate 2017 https://www.strate.co.za/blog/2017/11/nasdaq-to-deliver-blockchain-evoting-solution-to-strate/.

98 Strate 2017 https://www.strate.co.za/blog/2017/11/nasdaq-to-deliver-blockchain-evoting-solution-to-strate/. 
the proxy exercises the shareholder's rights at the particular shareholders' meeting. In view of the common corporate practice of inserting provisions in the MOI disqualifying "late" proxies, a good number of companies in South Africa will have to amend the relevant provisions in their MOls to align them with this correct legal position.

I have also compared the approach in South Africa in terms of section 58(1) read with section 58(3)(c) of the Companies Act 71 of 2008 with the approach in the UK, Australia, New Zealand, Kenya, Canada and India. It appears that the South African legislature has deliberately deprived companies of the flexibility to specify a minimum period for the submission of proxies. Such flexibility would have been vital to ensuring the proper administration of proxies before the start of the meeting. Instead, the South African legislature has opted for an unconstrained right to appoint a proxy "at any time" before the proxy exercises the proxy giver's rights at the meeting. I have pointed out that the approach adopted by the South African legislature in this regard is out of step with the trend in comparable international jurisdictions and may potentially give rise to far-reaching practical difficulties for companies and shareholders in relation to the conduct of meetings. It is therefore submitted that the legislature should consider the unintended consequences of affording shareholders an unconstrained right to appoint a proxy "at any time" and, if deemed necessary, should amend section 58 of the Companies Act 71 of 2008 as suggested in this case note. The legislature should also amend section $58(3)$ (c) to remove the anomaly in the current formulation of that provision as an "alterable" provision of the Companies Act 71 of 2008 . In addition, I have suggested that, in the meantime, companies should find innovative ways to mitigate the practical challenges associated with the submission of a large number of proxies at the meeting. The development and adoption of the e-voting system for listed companies could be a positive development in the South African markets, as it would improve the current administrationintensive proxy voting system for such companies. I have, however, pointed out that the effectiveness of a system such as e-voting, in so far as the appointment of proxies and proxy voting are concerned, would depend, among other things, on the successful implementation and widespread accessibility of the system to companies, shareholders and proxies.

\section{Bibliography}

\section{Literature}

Cassim et al Contemporary Company Law

Cassim FHI et al Contemporary Company Law $2^{\text {nd }}$ ed (Juta Claremont 2012) 
Davis et al Companies and Other Business Structures

Davis D et al Companies and other Business Structures in South Africa $3^{\text {rd }}$ ed (Oxford University Press Cape Town 2013)

Delport Henochsberg

Delport P Henochsberg on the Companies Act 71 of 2008 (LexisNexis Butterworths Durban 2011)

Du Plessis and Mathiopoulos 2016 Aust Jnl of Corp Law

Du Plessis JJ and Mathiopoulos JA "Defences and Relief from Liability for Company Directors: Widening Protection to Stimulate Innovation" 2016 Aust Jnl of Corp Law 287-318

Stein and Everingham New Companies Act Unlocked

Stein C and Everingham G The New Companies Act Unlocked (Siber Ink Cape Town 2011)

Stoop 2016 JCCL\&P

Stoop H "Alterable and Unalterable Provisions of the Companies Act 71 of 2008: Recent Cases Expose Inherent Uncertainties" 2016 JCCL\&P 40-51

\section{Case law}

Du Plessis Barry v Clearwater Estates NPC (GP) (unreported) case number 82306/2014 of 13 November 2015

Natal Joint Municipal Pension Fund v Endumeni Municipality [2012] ZASCA 13 (16 March 2012)

Nuwe Suid-Afrikaans Prinsipale Beleggings (Edms) Bpk $v$ Saambou Holdings Ltd 19924 SA 387 (W)

$R v$ Shole 19604 SA 781 (A)

Richard Du Plessis Barry v Clearwater Estates NPC [2017] ZASCA 11 (16 March 2017)

\section{Legislation}

\section{Australia}

Corporations Act, 2001

\section{Canada}

Business Corporations Act, 1985 
India

Companies Act, 2013

\section{Kenya}

Companies Act, 2015

New Zealand

Companies Act, 1993

\section{South Africa}

Companies Act 61 of 1973

Companies Act 71 of 2008

\section{UK}

Companies Act, 1985

Companies Act, 2006

\section{Government publications}

GN 1183 in GG 26493 of 23 June 2004

GN 969 in GG 41913 of 21 September 2018

\section{Internet sources}

Cashbuild Limited 2017 http://www.cashbuild.co.za/Reports/2017/ Tabs/notice_of_annual_general_meeting.pdf

Cashbuild Limited 2017 Notice of Annual General Meeting http://www.cashbuild.co.za/Reports/2017/Tabs/notice_of_annual_general_ meeting.pdf accessed 22 December 2017

Strate 2017 https://www.strate.co.za/blog/2017/11/nasdaq-to-deliverblockchain-e-voting-solution-to-strate/

Strate 2017 Nasdaq to Deliver Blockchain e-Voting Solution to Strate https://www.strate.co.za/blog/2017/11/nasdaq-to-deliver-blockchain-evoting-solution-to-strate/ accessed 13 November 2018

Super Group Limited $2017 \quad$ http://supergroup.co.za/2017_ integrated_report/downloads/supergroup_agm.pdf 
Super Group Limited 2017 Notice of Annual General Meeting http://supergroup.co.za/2017_integrated_report/downloads/supergroup_ag m.pdf accessed 22 December 2017

\section{List of Abbreviations}

$\begin{array}{ll}\text { AGM } & \text { Annual General Meeting } \\ \text { Aust Jnl of Corp Law } & \begin{array}{l}\text { Australian Journal of Corporate Law } \\ \text { Department of Trade and Industry } \\ \text { DTI }\end{array} \\ \text { JCCL\&P } & \begin{array}{l}\text { Journal of Corporate and Commercial Law } \\ \text { and Practice }\end{array} \\ \text { MOI } & \text { Memorandum of Incorporation } \\ \text { SCA } & \text { Supreme Court of Appeal } \\ \text { UK } & \text { United Kingdom }\end{array}$

